\title{
Sustainability science for meeting Africa's challenges: setting the stage
}

\author{
Alexandros Gasparatos $^{1} \cdot$ Kazuhiko Takeuchi $^{1,2} \cdot$ Thomas Elmqvist $^{4}$ \\ Kensuke Fukushi ${ }^{1} \cdot$ Masafumi Nagao $^{3}$ - Frans Swanepoel ${ }^{5} \cdot$ Mark Swilling $^{6}$. \\ Douglas Trotter $^{7} \cdot$ Harro von Blottnitz $^{8}$
}

Published online: 6 September 2017

(c) Springer Japan KK 2017

\section{Sustainability challenges in sub-Sahara Africa}

Sub-Sahara Africa (SSA) is experiencing striking antitheses. Despite the long-term efforts to alleviate poverty, poverty still remains endemic in several of its regions (UNDP 2014). Currently, SSA contains a large fraction of the world's poor and while poverty rates have declined drastically over time, it may take a substantial amount of time before chronic and multi-dimensional poverty is eradicated (World Bank 2016; UNDP 2014). This is particularly troubling as Africa is in fact blessed with abundant natural resources that could potentially assist its development. In reality, however, these resources are not always evenly distributed among segments of society or can have tremendous negative environmental impacts if mismanaged.

For example, while large tracts of land are allocated across Africa for large-scale agricultural production to spur economic development (Schoneveld 2014), the continent

Alexandros Gasparatos

gasparatos@ir3s.u-tokyo.ac.jp

IR3S, University of Tokyo, Tokyo, Japan

2 Institute for Global Environmental Strategies (IGES), Hayama, Japan

3 United Nations University, Tokyo, Japan

4 Stockholm Resilience Center, Stockholm University, Stockholm, Sweden

5 University of the Western Cape, Cape Town, South Africa

6 University of Stellenbosch, Stellenbosch, South Africa

7 Council for Scientific and Industrial Research (CSIR), Durban, South Africa

8 University of Cape Town, Cape Town, South Africa registers some of the highest levels of under-nutrition and food insecurity globally (EIU 2015). At the same time some agricultural practices in SSA have been blamed for causing extensive land use change and environmental degradation (Reynolds et al. 2015). While, growth in the agricultural sector is challenged by an uncertain policy environment, poor infrastructural development and increasing post-harvest losses, among others (OECD/FAO 2016), enhancing the actual sustainability of the agricultural sector is a much more difficult puzzle to solve.

Mining is another example of how the rich natural resource base of the continent does not always translate into positive sustainability outcomes. For example while mining has catalyzed economic development in some areas (UNECA 2011, 2013), it has often been detrimental to the natural environment (Edwards et al. 2013) and local communities (Hilson 2009). Several scholars have pointed that the paradigm of building development (let alone a sustainable development) based on resource extraction could, in fact, be misleading as attested by the signs of possible resource curse in some SSA countries (Badeeb et al. 2017).

At the same time SSA host some pristine and highly biodiverse ecosystems, including eight of the 36 global biodiversity hotspots (Mittermeier et al. 2011). While the extent of protected areas has been increasing in SSA in the past decades (UNEP-WCMC 2016), protected and nonprotected areas are facing significant pressure as they cater for multiple human needs ranging from fuelwood to wild food and medicinal plants (Tranquilli et al. 2014; Brashares et al. 2011; UNEP 2010; Beresford et al. 2013; Laurance et al. 2012). In fact most African countries have little progress in meeting the Aichi Biodiversity Targets ratified during the 10th Conference of the Parties of the 
Convention on Biological Diversity (CBD-COP10) (UNEP-WCMC 2016).

The dual realities of a rapidly increasing population and global environmental change are expected to put further strain into the natural resource base of the continent. SSA is projected to experience some of the most severe impacts of anthropogenic climate change that will inevitably affect its social-ecological systems (Niang et al. 2014). At the same time the rapid urbanization (which shows unique patterns), the low access of urban populations to basic amenities and materials (e.g., nutritious food, modern fuels, sanitation), and the increasing vulnerability of these populations to environmental change can be observed throughout the continent (World Bank 2013). Other studies have outlined a series of important sustainability challenges related to employment generation (UNEP 2015), access to clean and affordable energy (Avila et al. 2017; Morrissey 2017), lack of proper access to water/sanitation/ hygiene (WSP 2011), and increasing levels of indoor/outdoor pollution and waste (e.g., Amegah and Agyei-Mensah 2017; Oteng-Ababio et al. 2013). The combination of the above might take a significant toll on public health and stifle development opportunities well into the future (UNHabitat 2015).

The above are only some of the multi-faceted and usually intertwined sustainability challenges that countries across SSA currently face, and will be facing in the decades to come. There is an urgent need to solve these challenges in a socially inclusive and environmentally sustainable manner if the recently agreed Sustainable Development Goals (SDGs) are to be met in the region by 2030. However, there are serious concerns whether countries in the SSA will manage to meet the SDGs (UNECA 2015a) considering the low level of success in meeting some of the Millennium Development Goals (UNECA 2015b).

\section{Sustainability science in Africa}

Sustainability science is characterized by its solution-oriented approach, ability to link social and ecological systems, and inter- and transdisciplinary perspective (Kates 2011; Komiyama and Takeuchi 2006). It is thus well positioned to lead the research agenda and to offer key insights on how to address development challenges in SSA. However, can sustainability science, as a field of inquiry, also help achieve this in the African context?

Leading scholars of sustainability science have discussed that sustainability science could (and should) engage seriously with the grand challenges that Africa faces, such as poverty (Kates and Dasgupta 2007). For example, a Special Feature published by Sustainability
Science in 2011 aimed to discuss from multiple perspectives how sustainability science could engage with some of these challenges in Africa (Takeuchi and Obijiofor 2011). Such studies make the case that sustainability scientists working in SSA contexts would be advised to cultivate a visible and strong link to development issues, as these are generally still regarded to be very policy-relevant and can attract political support.

Currently, an increasing number of studies have been applying sustainability science concepts and principles in SSA contexts. However, a recent meta-analysis of publication trends in the field of sustainability science has shown that despite strong research connections between African and EU/US/Canadian institutions, there is a low number of sustainability science studies solely by African scholars (Elsevier 2015). Actually scholars from African countries tend to be mostly at the margin of the global sustainability science network, having low-intensity connections with the core of the network (Elsevier 2015).

Burns and Weaver (2008) have led one of the few structured efforts to frame sustainability science purely with African voices and perspectives. In particular, they collated various several examples of sustainability science research from South Africa using a wealth of methodological approaches. At the same time there are some efforts to develop dedicated sustainable development and/ or sustainability science research institutions and educational curricula in countries such as South Africa and Ghana. However, despite these scattered efforts to create a research and education base on sustainability science in the region, several challenges remain related to how to integrate more meaningfully African voices and perspectives within the field.

Some scholars advocate that these diverse worldviews should be merged to create a third space for dialogue and curriculum development (Glasson et al. 2010). Such views are echoed in the current work of the Intergovernmental Science-Policy Platform on Biodiversity and Ecosystem Services (IPBES) (e.g., Pascual et al. 2017; Roué et al. 2016). On the other hand, scholars such as Chilisa (2012), albeit not coming purely from within the field of sustainability science, have advocated for the decolonization of science calling for African scholars to raise their own voice and transform constructively sustainability science scholarship and practice (Chilisa 2017).

Notwithstanding these two sides of the debate, the fact remains that the interface between sustainability science, indigenous research paradigms, and indigenous and local knowledge (ILK) remains largely unexplored in SSA. For example, a recent Special Feature published by Sustainability Science focused on this interface, but had little content from SSA (Johnson et al. 2016). 


\section{Aims and structure of the Special Feature}

In order to tackle effectively the interconnected sustainability challenges that Africa currently experiences there is a strong need to develop transdisciplinary and problemoriented research.

The Special Feature collects contributions from leading scholars that apply Sustainability Science concepts and principles in the African context. As highlighted in Table 1, some of the sustainability challenges that are considered in this Special Feature include (but are not confined to) agriculture and food security, biodiversity and conservation, climate change adaptation, urbanization and urban sustainability, natural resources management, economic development and poverty alleviation, and the preservation of ILK systems. At the same time, each paper offers insights that relate directly to some of the key aspects of sustainability science discussed above (Table 2).

Toth et al. (2017) explore the constraints that smallholder farmers in Malawi face for the adoption of improved agricultural technologies. In particular they focus on the agro-forestry practices such as Fodder Tree Technology (FTT). They use a combination of statistical tools to understand how different socioeconomic and environmental characteristics influence the decision to adopt FFT.

Chaudhury et al. (2017) outline a methodological approach that can be used to identify and implement climate change adaptation actions in subsistence agricultural settings. They discuss a transdisciplinary approach that allows the establishment of linkages between the local communities that are in dire need of climate change adaptation interventions in northern Ghana and regional/national stakeholders.

Dam et al. (2017) develop a rapid appraisal methodology for assessing the local food security outcomes of industrial crop expansion in smallholder settings of Africa. They develop a metric of household caloric intake that captures food security across its four pillars (i.e., availability, access, utilization, stability), but also considers gender roles, and especially the toll that unpaid household work can take on household food security. This methodology is applied in areas of smallholder industrial crop expansion in Ghana (cotton) and Ethiopia (sugarcane). Results suggest the variable food security outcomes between industrial crop growers (intervention group) and non-industrial crop growers (control groups).

Assefa and Bork (2017) highlight different ILK practices adopted in the Gamo Highland of Ethiopia to manage agricultural land, forests, woodland, grazing land and soil resources. They identify how these ILK practices are embedded in the local culture and have allowed local communities to survive under adverse environmental

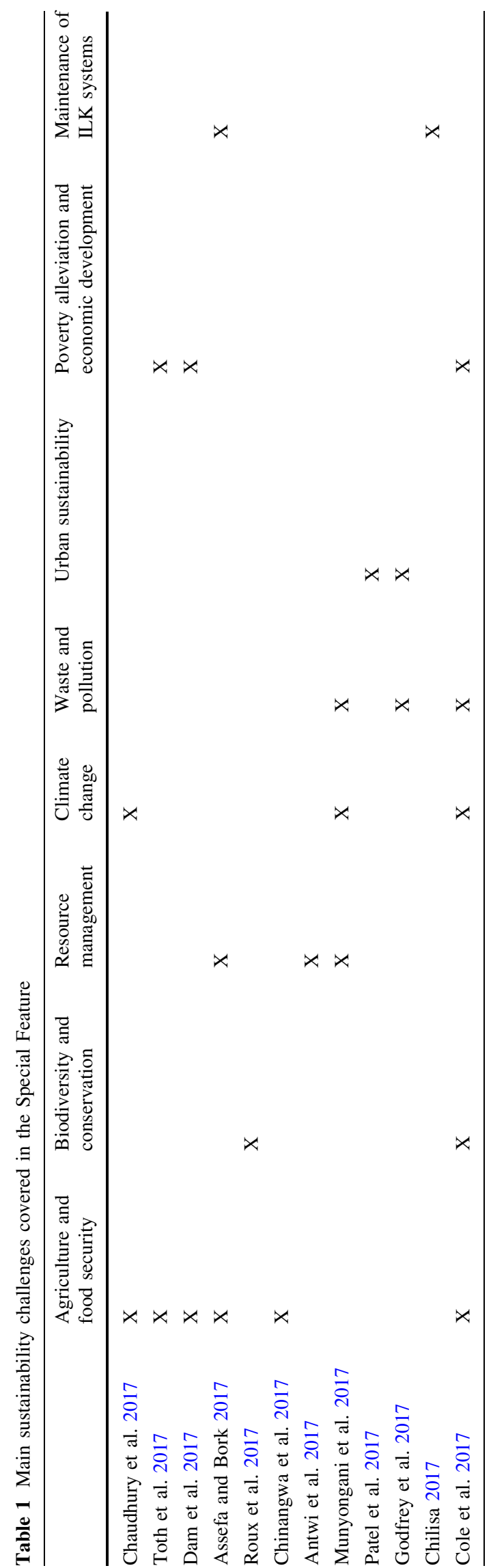


Table 2 Main aspects of sustainability science covered in the Special Feature

\begin{tabular}{|c|c|c|c|}
\hline & Transdisciplinary approach & Social-ecological systems approach & Solution-oriented approach \\
\hline Chaudhury et al. 2017 & $\mathrm{X}$ & & $\mathrm{X}$ \\
\hline Toth et al. 2017 & & $\mathrm{X}$ & $\mathrm{X}$ \\
\hline Dam et al. 2017 & & $\mathrm{X}$ & \\
\hline Assefa and Bork 2017 & $\mathrm{X}$ & $\mathrm{X}$ & \\
\hline Roux et al. 2017 & $\mathrm{X}$ & $\mathrm{X}$ & \\
\hline Chinangwa et al. 2017 & $\mathrm{X}$ & $\mathrm{X}$ & \\
\hline Antwi et al. 2017 & $\mathrm{X}$ & $\mathrm{X}$ & \\
\hline Munyongani et al. 2017 & $\mathrm{X}$ & & $\mathrm{X}$ \\
\hline Patel et al. 2017 & $\mathrm{X}$ & & $\mathrm{X}$ \\
\hline Godfrey et al. 2017 & & & $X$ \\
\hline Chilisa 2017 & $\mathrm{X}$ & & \\
\hline Cole et al. 2017 & & $X$ & $\mathrm{X}$ \\
\hline
\end{tabular}

conditions for centuries. Subsequently, they delve into the socioeconomic factors that have catalyzed the currently observed changes in the deployment of such ILK practices. The study makes a strong case for the cross-fertilization of ILK practices with modern scientific knowledge to maximize the effectiveness of ongoing efforts to conserve soil resources in Ethiopia.

Roux et al. (2017) focus on the mutual learning effects that can manifest within transdisciplinary sustainability science research projects. They use the comparative analysis of two biodiversity conservation projects in South Africa of varying scales and durations to identify three aspects that could guide sustainability science scholars to design and facilitate such learning (i.e., who to learn with, what to learn about, and how to learn). They outline learning heuristics and extract five generic lessons for sustainability science scholars to enhance the success of transdisciplinary projects.

Chinangwa et al. (2017) explore whether market-based forest conservation mechanisms, such as Payment for Ecosystem Services (PES) schemes, can appeal to private companies in the industrial crop sector. Through expert interviews with key stakeholders at the interface of industrial crop production and forest conservation, they draw insights about the acceptability of such schemes in the tobacco and sugarcane sector in Malawi. They identify that the private sector would be willing to be involved in PES schemes only if they are embedded in existing corporate activities such as Corporate Social Responsibility (CSR) initiatives and credit-based activities to their outgrowers.

Antwi et al. (2017) develop a composite index to assess the local sustainability impacts of mining. They use the case of a gold mine in Ghana to elicit how mining activities have had a series of environmental, social, economic and institutional impacts to three local communities (two resettled communities and one non-resettled). They find that despite the large similarities in their ecological context, some sustainability impacts can differ substantially between communities due to processes that unfolded during and after their relocation. They identify the need to move beyond simple landscape restoration, and to consider in restoration efforts the broad suite of local sustainability impacts that mining can have in Africa.

Munyongani et al. (2017) explore how Life Cycle Analysis (LCA) can be used to inform design processes in the mining sector. They conduct a retrospective comparative analysis of sulfur dioxide mitigation installations in the platinum group metal industry in South Africa. They quantify reductions or burden shifts for a range of environmental impacts associated with the adoption of these technologies. Subsequently, they report the outcomes of interviews with industry experts on whether and how this advanced environmental analysis tool could have been used to support design decision-making as a means of enhancing the sustainability of the mining sector.

Patel et al. (2017) outline an urban experiment in Cape Town that assessed the feasibility of implementing SDG $11^{1}$ in urban settings of Africa prior to its ratification by the UN General Assembly. The findings of the urban experiment illustrate both the complex intra-local and multi-level governance arrangements that underpin the acquisition of the necessary data for reporting on the targets and indicators of SDG11. They highlight partnership arrangements that can allow African cities meet the data and governance challenges, which are central to SDG11. The outcomes of this experiment contributed to significant

\footnotetext{
${ }^{1}$ The main aim of SDG11 is to "Make cities and human settlements inclusive, safe, resilient and sustainable".
} 
revisions in the final targets and indicators of SDG11, thus highlighting the potential of urban experimentation to break from the usual top-down monitoring and evaluation of indicators.

Godfrey et al. (2017) study the employment generation potential and the challenges that waste co-operatives face in South Africa. Through a series of expert interviews with members of waste co-operatives and other experts they identify key challenges in the sector such as the high mortality rate of co-operatives, the high member turnover rate, the low capacity and a series of other institutional barriers that take a toll on the viability of most of these ventures. They highlight three necessary criteria to improve the employment/income generation potential and the formalization of the solid waste management sector in South Africa: access to materials, access to markets, and business development support.

Chilisa (2017) outlines a typology of indigenous research approaches based on African perspectives, and unravels their key ontological and epistemological assumptions. These approaches epitomize ILK as a body of thought that legitimizes ILK holders, practitioners and communities as scholars and authors of "what they know" and "how it can be known". She makes the case that such indigenous research approaches question academic and methodological imperialism, and can improve solutionoriented research in Africa. The methodological frameworks and typologies presented in this article can be used to ensure that transdisciplinary research geared towards meeting Africa's sustainability challenges is inclusive of African voices.

Cole et al. (2017) develop a methodology for tracking progress towards the SDGs at the sub-national level. They create visual tools that operationalize the concept of "safe and just operating space", and apply it for the nine provinces of South Africa. They highlight the large variation in environmental stress and social deprivation across improve provinces and emphasize how geographical location can affect progress towards sustainability. They outline three possible approaches for spatially disaggregating environmental data that can be used and in other African countries to assist the implementation of SDGs at the subnational level. Central to their approach is how to communicate the key sustainability challenges and risks that provincial governments face in a non-specialist, userfriendly and accessible way for various non-academic audiences.

Acknowledgments This special issue contains contributions from the 6th International Conference on Sustainability Science (ICSS 2016) held on 2-3 March 2016 in Stellenbosch, South Africa. This event was organized jointly by the University of Tokyo (IR3S), the United Nations University (Institute for the Advanced Study of Sustainability, UNU-IAS), the University of Stockholm (Stockholm Resilience
Centre), the University of the Western Cape, the University of Stellenbosch (Sustainability Institute), the Council for Scientific and Industrial Research (CSIR) and the University of Cape Town. Funding for this event was provided by the Japan Society for the Promotion of Science (JSPS) through its Core-to-Core programme (Project: 23001). Alexandros Gasparatos acknowledges the financial support of the Japan Science and Technology Agency (JST) for the Belmont Forum project FICESSA.

\section{References}

Amegah AK, Agyei-Mensah S (2017) Urban air pollution in SubSaharan Africa: time for action. Environ Pollut 220:738-743

Antwi E, Owusu-Banahene Y, Boakye-Danquah J, Mensah R, Tetteh JD, Nagao M, Takeuchi K (2017) Sustainability assessment of mine affected communities in ghana: towards ecosystems and livelihoods restoration. Sustain Sci. doi:10.1007/s11625-0170474-9

Assefa ET, Bork HR (2017) Indigenous resource management practices in the Gamo Highland of Ethiopia: challenges and prospects for sustainable resource management. Sustain Sci. doi:10.1007/s11625-017-0468-7

Avila N, Carvallo JP, Shaw B, Kammen D (2017) The energy challenge in sub-Saharan Africa: a guide for advocates and policy makers: generating energy for sustainable and equitable development. Oxfam America, Boston

Badeeb RA, Lean HH, Clark J (2017) The evolution of the natural resource curse thesis: a critical literature survey. Resour Policy 51:123-134

Beresford AE, Eshiamwata GW, Donald PF, Balmford A, Bertzky B, Brink AB, Fishpool LDC, Mayaux P, Phalan B, Simonetti D, Buchanan GM (2013) Protection reduces loss of natural landcover at sites of conservation importance across Africa. PLoS One 8:e65370

Brashares JS, Golden CD, Weinbaum KZ, Barrett CB, Okello GV (2011) Economic and geographic drivers of wildlife consumption in rural Africa. PNAS 108:13931-13936

Burns M, Weaver A (eds) (2008) Exploring sustainability science: a southern African perspective. African SUN MeDIA, Stellenbosch

Chaudhury A, Helfgott A, Thornton TF, Sova C (2017) Applying the robust adaptation planning (RAP) framework to Ghana's agricultural climate change adaptation regime. Sustain Sci. doi:10. 1007/s11625-017-0462-0

Chilisa B (2012) Indigenous research methodologies. Sage, Thousand Oaks

Chilisa B (2017) Decolonising transdisciplinary research approaches: an African perspective for enhancing knowledge integration in sustainability science. Sustain Sci. doi:10.1007/s11625-0170461-1

Chinangwa L, Gasparatos A, Saito O (2017) Forest conservation and the private sector: stakeholder perceptions towards payment for ecosystem services schemes in the tobacco and sugarcane sectors in Malawi. Sustain Sci. doi:10.1007/s11625-017-0469-6

Cole M, Bailey RM, New MG (2017) Spatial variability in sustainable development trajectories in South Africa: provincial level safe and just operating spaces. Sustain Sci. doi:10.1007/ s11625-016-0418-9

Dam LR, Boafo YA, Degefa S, Gasparatos A, Saito O (2017) Assessing the food security outcomes of industrial crop expansion in smallholder settings: insights from cotton production in Northern Ghana and sugarcane production in Central Ethiopia. Sustain Sci. doi:10.1007/s11625-017-0449-x 
Edwards DP, Sloan S, Weng L, Dirks P, Sayer J, Laurance WF (2013) Mining and the African environment. Conserv Lett 7:302-311

EIU (2015) Global food security index 2015. The Economist Intelligence Unit, London

Elsevier (2015) Sustainability science in a global landscape. Elsevier, Amsterdam

Glasson GE, Mhango N, Phiri A, Lanier M (2010) Sustainability science education in Africa: negotiating indigenous ways of living with nature in the third space. Int J Sci Educ 32:125-141

Godfrey L, Muswema A, Strydom W, Mamafa T, Mapako M (2017) Co-operatives as a development mechanism to support job creation and sustainable waste management in South Africa. Sustain Sci. doi:10.1007/s11625-017-0442-4

Hilson G (2009) Small-scale mining, poverty and economic development in sub-Saharan Africa: an overview. Resour Policy $34: 1-5$

Johnson JT, Howitt R, Cajete G, Berkes F, Louis RP, Kliskey A (2016) Weaving Indigenous and sustainability sciences to diversify our methods. Sustain Sci 11:1-11

Kates RW (2011) What kind of a science is sustainability science? PNAS 108:19449-19450

Kates RW, Dasgupta P (2007) African poverty: a grand challenge for sustainability science. PNAS 104:16747-16750

Komiyama H, Takeuchi K (2006) Sustainability Science: building a new discipline. Sustain Sci 1:1-6

Laurance WF et al (2012) Averting biodiversity collapse in tropical forest protected areas. Nature 489:290-294

Mittermeier RA, Turner WR, Larsen FW, Brooks TM and Gascon, C (2011) Global biodiversity conservation: the critical role of hotspots. In: Zachos F, Habel J (eds) Biodiversity hotspots. Springer, Berlin, pp 3-22

Morrissey J (2017) The energy challenge in sub-Saharan Africa: A guide for advocates and policy makers: Addressing energy poverty. Oxfam America, Boston

Munyongani V, von Blottnitz H, Broadhurst J (2017) A life-cyclebased review of sulfur dioxide abatement installations in the South African platinum group metal sector. Sustain Sci. doi:10. 1007/s11625-017-0467-8

Niang I, Ruppel OC, Abdrabo MA, Essel A, Lennard C, Padgham J et al (2014) Africa. Climate change 2014: Impacts, adaptation, and vulnerability. Part B: Regional aspects In: Barros VR, Field $\mathrm{CB}$, Dokken DJ, Mastrandrea MD, Mach KJ, Bilir TE, Chatterjee M, Ebi KL, Estrada YO, Genova RC, Girma B, Kissel ES, Levy AN, MacCracken S, Mastrandrea PR White LL (eds) In: Contribution of working group II to the fifth assessment report of the intergovernmental panel of climate change. Cambridge University Press, Cambridge, United Kingdom and New York, NY, USA, pp 1199-1265

OECD/FAO (2016) OECD-FAO agricultural outlook 2016-2025. OECD, Paris

Oteng-Ababio M, Melara Arguello JE, Gabbay O (2013) Solid waste management in African cities: sorting the facts from the fads in Accra, Ghana. Habitat Int 39:96-104

Pascual U, Balvanera P, Díaz S, Pataki G, Roth E, Stenseke M, Watson RT, Yagi N (2017) Valuing nature's contributions to people: the IPBES approach. Curr Opin Environ Sustain 2017(26):7-16

Patel Z, Greyling S, Simon D, Arfvidsson H, Moodley N, Primo N, Wright C (2017) Local responses to global sustainability agendas: learning from experimenting with the urban sustainable development goal in Cape Town. Sustain Sci. doi:10.1007/ s11625-017-0465-x

Reynolds TW, Waddington SR, Anderson CL, Chew A, True Z, Cullen A (2015) Environmental impacts and constraints associated with the production of major food crops in Sub-Saharan Africa and South Asia. Food Secur 7:795-822

Roué M, Césard N, Adou Yao YC, Oteng-Yeboah A (eds) (2016) Indigenous and local knowledge of biodiversity and ecosystem services in Africa. UNESCO, Paris

Roux D, Nel J, Cundill G, O'Farrell P, Fabricius C (2017) Transdisciplinary research for systemic change: who to learn with, what to learn about and how to learn. Sustain Sci. doi:10. 1007/s11625-017-0446-0

Schoneveld GC (2014) The geographic and sectoral patterns of largescale farmland investments in sub-Saharan Africa. Food Policy 48:34-50

Takeuchi K, Obijiofor A (2011) Sustainability challenges and opportunities in Africa. Sustain Sci 6:3-5

Toth G, Nair PKR, Duffy CP, Franzel SC (2017) Constraints to the adoption of fodder tree technology in Malawi. Sustain Sci. doi:10.1007/s11625-017-0460-2

Tranquilli S, Abedi-Lartey M, Abernethy K, Amsini F, Asamoah A, Balangtaa $\mathrm{C}$ et al (2014) Protected areas in tropical Africa: assessing threats and conservation activities. PLoS One 9(12):e114154. doi:10.1371/journal.pone.0114154

UNDP (2014) Human development report 2014. United Nations Development Programme (UNDP), New York

UNECA (2011) Minerals and Africa's development. United Nations Economic Commission for Africa (UNECA), Addis Ababa

UNECA (2013) Managing Africa's natural resource base for sustainable growth and development. United Nations Economic Commission for Africa (UNECA), Addis Ababa

UNECA (2015a) Africa regional report on the sustainable development goals. United Nations Economic Commission for Africa (UNECA), Addis Ababa

UNECA (2015b) MDG Report 2015: assessing progress in Africa toward the millennium development goals. United Nations Economic Commission for Africa (UNECA), Addis Ababa

UNEP (2010) State of biodiversity in Africa. United Nations Environmental Programme (UNEP), Nairobi

UNEP (2015) Building inclusive green economies in Africa: experience and lessons learned 2010-2015. United Nations Environmental Programme (UNEP), Nairobi

UNEP-WCMC (2016) The state of biodiversity in Africa: a mid-term review of progress towards the Aichi Biodiversity Targets. UNEP-WCMC, Cambridge

UN-Habitat (2015) The state of African cities 2014: re-imagining sustainable urban transitions. United Nations Human Settlements Programme (UN-Habitat), Nairobi

World Bank (2013) Harnessing urbanization to end poverty and boost prosperity in Africa. World Bank, Washington DC

World Bank (2016) Poverty in a rising Africa. World Bank, Washington DC

WSP (2011) Sanitation and hygiene in Africa at a glance: a synthesis of country priority actions. Water and Sanitation Programme, Washington DC 